\title{
MATHEdunesa
}

Jurnal IImiah Pendidikan Matematika Volume 9 No. 1 Tahun 2020

ISSN :2301-9085

\section{PENGARUH PENDEKATAN PENDIDIKAN MATEMATIKA REALISTIK INDONESIA (PMRI) TERHADAP HASIL BELAJAR SISWA}

\author{
Maria Margaretha Faot \\ Pendidikan Matematika, FMIPA, Universitas Negeri Surabaya \\ e-mail: mariafaot@mhs.unesa.ac.id \\ Siti Maghfirotun Amin \\ Pendidikan Matematika, FMIPA, Universitas Negeri Surabaya \\ e-mail: sitiamin@unesa.ac.id
}

\begin{abstract}
Abstrak
Penelitian ini bertujuan untuk mengetahui apakah pembelajaran dengan pendekatan PMRI berpengaruh terhadap hasil belajar matematika siswa. Penelitian ini dilaksanakan di Kelas VIII SMPN 2 Gedangan Sidoarjo Semester Gasal Tahun Pelajaran 2019/2010 pada materi pola bilangan. Penelitian ini adalah eksperimen yang bertujuan untuk mengetahui pengaruh pendekatan PMRI terhadap hasil belajar siswa. Rancangan yang digunakan adalah control group pre-test-post-test design. Teknik pengumpulan data melalui tes (pretest-posttest). Berdasarkan perhitungan hasil belajar (pretest \& posstest) kelas eksperimen dan kelas kontrol masing-masing berasal dari populasi yang berdistribusi normal. Dari persamaan regresi menunjukkan bahwa pembelajaran dengan pendekatan PMRI berpengaruh terhadap hasil belajar siswa. Berdasarkan perhitungan dengan SPSS (Statistical Product and Service Solution) nilai signifikansi $<\alpha$, dimana nilai $\alpha$ yaitu 0,05 dan diperoleh nilai signifikansi 0,014. Berdasarkan pedoman pengambilan keputusan, maka didapatkan hasil bahwa pendekatan PMRI memengaruhi hasil belajar siswa.

Kata kunci : Pendidikan Matematika Realistik Indonesia (PMRI), Hasil Belajar Siswa.
\end{abstract}

\section{Abstract}

This study aims to determine whether learning with the PMRI approach influences student learning outcomes in mathematics. This research was conducted in Class VIII SMPN 2 Gedangan Sidoarjo Odd Semester 2019/2010 Academic Year on material number patterns. This study is an experiment that aims to determine the effect of the PMRI approach to student learning outcomes. The design used is the control group pre-test-post-test design. Data collection techniques through tests (pretest-posttest). Based on the calculation of learning outcomes (pretest \& posstest) the experimental class and the control class each come from a normally distributed population. The regression equation shows that learning with the PMRI approach influences student learning outcomes. Based on calculations with SPSS (Statistical Product and Service Solution) significance value $<\alpha$, where the $\alpha$ value is 0.05 and a significance value of 0.014 is obtained. Based on the decision making guidelines, the results are obtained that the PMRI approach influences student learning outcomes.

Keyword : Indonesia's realistic mathematics education, student learning outcomes.

\section{PENDAHULUAN}

Matematika memiliki peranan penting dalam bidang pendidikan. Dapat dilihat dari matematika yang diajarkan di setiap jenjang pendidikan, mulai dari SD sampai perguruan tinggi. Ini menunjukkan bahwa matematika menjadi suatu keharusan bagi siswa untuk dipelajari. Dalam proses mempelajari matematika, siswa dituntut untuk mencapai kompetensi yang telah ditetapkan oleh kurikulum.

Siswa Indonesia telah berpartisipasi pada studi Trends in International Mathematics and Science Study (TIMSS). Hasil TIMSS tahun 1999 menginformasikan diantara 38 negara peserta, prestasi siswa SMP Kelas II Indonesia berada pada urutan ke-34 untuk matematika (Rosyada, 2004: 3). Selanjutnya pada tahun 2007 menginformasikan bahwa di antara 49 negara peserta, prestasi siswa SMP Kelas VII Indonesia ada pada urutan ke-36 masih berada di bawah rata-rata Internasional.
Untuk SMP baik negeri maupun swasta, tahun 2016 dengan jumlah satuan pendidikan 53.660 rata-rata nilai ujian matematika 50,24. Tahun 2017 dengan jumlah satuan pendidikan 54.774 rata-rata nilai ujian matematika 50,31. Sedangkan tahun 2018 dengan jumlah 55.708 satuan pendidikan mencapai rata-rata nilai ujian matematika 43,34 masuk dalam kategori kurang (Puspendik, 2018).

Rendahnya prestasi matematika siswa dapat disebabkan oleh pemahaman siswa tentang konsep matematika sangat lemah karena belajar matematika kurang bermakna untuk siswa (Suharta, 2005: 1). Selain itu menurut Soedjadi (2000) salah satu karakteristik matematika adalah memiliki objek kajian abstrak, inilah penyebab tidak sedikit siswa mengalami kesulitan dalam matematika.

Sejalan dengan itu diperlukan suatu pendekatan yang membuat belajar matematika bermakna bagi siswa sehingga memberikan pengalaman berharga dan 
bernuansa lain kepada siswa. Salah satu pendekatan yang dapat diberikan ialah pendekatan Pendidikan Matematika Realistik Indonesia (PMRI). Dalam PMRI, siswa diberi kesempatan untuk menemukan kembali ide atau konsep matematika sebagai akibat dari pengalaman siswa dalam berinteraksi dengan dunia nyata (Azizah, 2015). Sesuai bahwa dalam pengajaran PMRI dibangun di atas pengetahuan formal, artinya pengetahuan tentang topik yang anak-anak belajar melalui pengalaman di luar kelas (Putri, R.I.I., \& Zulkardi, 2019). Karakteristik PMR yang dikemukakan Treffers (dalam Ariyadi Wijaya, 2012) yaitu (1) Penggunaan konteks; (2) Penggunaan model matematisasi progresif; (3) Pemanfaatan hasil konstruksi siswa; (4) Interaktivitas; (5) Keterkaitan. Menurut Suwarsono (2001) salah satu kelebihan pembelajaran dengan PMR adalah siswa diberi pemahaman yang jelas tentang kegunaan matematika dengan kehidupan sehari-hari. Dengan menggunakan pendekatan, siswa akan lebih mudah menerima apa yang dipelajari serta termotivasi belajar matematika dan ingatan siswa dalam pelajaran akan lebih melekat. Penerapan pendekatan PMRI pada materi perbandingan di Kelas VIII-F SMP Negeri 1 Turi (Izzabella, 2017) ialah penelitian yang relevan dengan masalah di atas.

Berdasarkan latar belakang, maka peneliti tertarik melakukan penelitian untuk melihat pengaruh pendekatan Pendidikan Matematika Realistik Indonesia (PMRI) terhadap hasil belajar siswa.

\section{METODE}

Rancangan penelitian ini adalah Control group pretest-post-test. Setelah hasil pretest dua kelompok didapat, kelas eksperimen diberi perlakuan (X), sedangkan kelas kontrol tidak diberi perlakuan (-). Kemudian pemberian posttest pada kedua kelas untuk mengetahui pengaruh perlakuan berdasarkan besar signifikansinya. Apabila ada perbedaan signifikan antara kelompok eksperimen \& kontrol, maka perlakuan yang diberikan berpengaruh secara signifikan.

Desain penelitian digambarkan sebagai berikut (Arikunto, 2010):

$$
\begin{array}{cccc}
\mathrm{E} & \mathrm{O}_{1} & \mathrm{X} & \mathrm{O}_{2} \\
\mathrm{~K} & \mathrm{O}_{1} & - & \mathrm{O}_{2}
\end{array}
$$

Keterangan :

E : kelompok eksperimen

$\mathrm{K}$ : kelompok kontrol

$\mathrm{X}$ : perlakuan (pendekatan PMRI)

- : diajar dengan pendekatan teacher centered approach

$\mathrm{O}_{1}$ : pemberian lembar tes (pretest)

$\mathrm{O}_{2}$ : pemberian lembar tes (posttest)

Berdasarkan hasil ujian (puspendik) pada tingkap SMP rendah. Maka penelitian dilaksanakan di tingkat SMP. Penelitian ini terdapat populasi yaitu siswa SMP Negeri 2 Gedangan kelas VIII dan sampel yang diambil adalah siswa dari dua kelas VIII SMP. Dari 11 kelas VIII yang ada, diberikan tes kemampuan awal yaitu beberapa materi yang ada di kelas VII. Tes kemampuan awal dilakukan dengan tujuan untuk memilih sampel penelitian. Dua kelas ini dijadikan sebagai sampel penelitian. Cluster random sampling digunakan sebagai teknik pengambilan sampel. Dua kelas yang dijadikan sampel dipilih dengan melihat ratarata hasil tes yang dilakukan. Untuk mengumpulkan data-data penelitian, digunakan tes pretest dan posttest. Ini dilakukan untuk mengetahui seberapa besar pemahaman siswa mengenai materi yang diperoleh dalam pembelajaran.

Teknik analisis data yang digunakan ialah uji normalitas, analisis regresi dan uji t. Uji normalitas yang digunakan adalah uji Kolmogorov-Smirnov. Uji normalitas bertujuan untuk mengetahui apakah hasil belajar siswa berdistribusi normal atau tidak. Dasar pengambilan keputusan, jika nilai signifikansi lebih dari 0,05 maka berdistribusi normal. Sedangkan, jika nilai signifikansi kurang dari 0,05 maka tidak berdistribusi normal.

Adapun teknik analisis data yang digunakan dalam penelitian ini adalah teknik Regression Analysis. Penelitian ini bertujuan untuk menemukan ada tidaknya pengaruh antar variabel. Apabila ada, seberapa eratnya pengaruh serta berarti atau tidaknya pengaruh itu. Untuk melakukan perhitungan peneliti menggunakan aplikasi SPSS. Uji t dilakukan untuk melihat adanya perbedaan antara kelas kontrol dengan kelas eksperimen. Jika nilai Sig. (2-tailed) $<0,05$, terdapat perbedaan signifikan antara hasil belajar pada kelas kontrol dan kelas eksperimen. Sebaliknya, jika nilai Sig. (2-tailed) > 0,05, maka tidak terdapat perbedaan yang signifikan antara hasil belajar pada kelas kontrol dan kelas eksperimen.

\section{HASIL DAN PEMBAHASAN}

\section{A. Hasil}

Pemilihan sampel penelitian dilakukan tes kemampuan awal pada setiap kelas VIII SMP Negeri 2 Gedangan. Tes kemampuan awal ini berisi soalsoal materi kelas VII. Terdapat sebelas kelas yang mengikuti tes kemampuan awal. Cluster random sampling merupakan teknik sampling daerah yang digunakan untuk menentukan sampel bila obyek ynag akan diteliti atau sumber data sangat luas (Sugiyono, 2013: 94). Kelas VIII-F dan VIII-G terpilih sebagai sampel penelitian. Pengambilan dua sampel penelitian berdasarkan hasil rata-rata kelas dengan selisih rata-rata sedikit pada tes kemampuan awal. Kedua kelas yang terpilih sebagai sampel penelitian melaksanakan pretest. Pretest diikuti oleh 60 siswa. Pada kelas kontrol diikuti 30 siswa juga kelas eksperimen diikuti 30 siswa. Waktu yang digunakan dalam pengerjaan pretest 30 menit. Peneliti memberitahu bahwa siswa mengerjakan secara individu dan jujur karena tes ini tidak berpengaruh pada nilai di sekolah.

Dari Tabel 1 kita mengetahui hasil pretest dari kelas VIII-F dengan rata-rata 57. Sedangkan hasil pretest dari kelas VIII-G dengan rata-rata 56,3.

Tabel 1. Nilai pretest

\begin{tabular}{|c|c|c|}
\hline \multirow{2}{*}{ No Absen } & \multicolumn{2}{|c|}{ Nilai Pretest } \\
\cline { 2 - 3 } & (VIII-F) & (VIII-G) \\
\hline 1 & 60 & 40 \\
\hline 2 & 60 & 60 \\
\hline
\end{tabular}




\begin{tabular}{|c|c|c|}
\hline \multirow[b]{2}{*}{ No Absen } & \multicolumn{2}{|c|}{ Nilai Pretest } \\
\hline & (VIII-F) & (VIII-G) \\
\hline 3 & 40 & 50 \\
\hline 4 & 70 & 70 \\
\hline 5 & 70 & 60 \\
\hline 6 & 60 & 60 \\
\hline 7 & 60 & 60 \\
\hline 8 & 60 & 70 \\
\hline 9 & 40 & 70 \\
\hline 10 & 60 & 50 \\
\hline 11 & 60 & 50 \\
\hline 12 & 40 & 60 \\
\hline 13 & 50 & 50 \\
\hline 14 & 60 & 60 \\
\hline 15 & 60 & 40 \\
\hline 16 & 50 & 60 \\
\hline 17 & 70 & 60 \\
\hline 18 & 70 & 50 \\
\hline 19 & 50 & 40 \\
\hline 20 & 60 & 50 \\
\hline 21 & 60 & 60 \\
\hline 22 & 40 & 60 \\
\hline 23 & 60 & 70 \\
\hline 24 & 50 & 50 \\
\hline 25 & 70 & 50 \\
\hline 26 & 60 & 60 \\
\hline 27 & 60 & 60 \\
\hline 28 & 60 & 60 \\
\hline 29 & 40 & 60 \\
\hline 30 & 60 & 50 \\
\hline Jumlah & 1710 & 1690 \\
\hline Rata-rata & 57 & 56,3 \\
\hline
\end{tabular}

Peneliti memberitahu bahwa siswa mengerjakan secara individu dan jujur karena tes ini tidak berpengaruh pada nilai di sekolah. Pelaksanaan perlakuan pembelajaran dengan PMRI di Kelas VIII$\mathrm{G}$ sesuai dengan perangkat pembelajaran. Langkahlangkah kegiatan sesuai karakteristik PMR.

Tabel 2. Langkah-langkah kegiatan sesuai dengan karateristik PMR

\begin{tabular}{|c|c|c|}
\hline No & Karakteristik & $\mathrm{C}=$ Contoh \\
\hline 1 & $\begin{array}{l}\text { Menggunaka } \\
\text { n masalah } \\
\text { kontekstual }\end{array}$ & $\begin{array}{l}\text { Mengaitkan } \\
\text { pembelajaran dengan } \\
\text { situasi lingkungan siswa. } \\
\text { Pak Ian membuat } \\
\text { beberapa desain kolam } \\
\text { berbentuk persegi. Tiap- } \\
\text { tiap kolam mempunyai } \\
\text { bentuk persegi pada area } \\
\text { penampung air dan diberi } \\
\text { ubin warna biru. Di } \\
\text { sekitar kolam dikelilingi } \\
\text { pembatas yang dipasang }\end{array}$ \\
\hline
\end{tabular}

\begin{tabular}{|c|c|c|c|}
\hline & & \multicolumn{2}{|c|}{$\begin{array}{l}\text { ubin warna putih. } \\
\text { Gambar berikut } \\
\text { menunjukkan desain tiga } \\
\text { kolam kecil } \\
\text { Pola yang terbentuk dari } \\
\text { ubin biru merupakan pola } \\
\text { bilangan persegi. }\end{array}$} \\
\hline \multirow[t]{9}{*}{2} & \multirow[t]{9}{*}{$\begin{array}{l}\text { Menggunaka } \\
\mathrm{n} \text { berbagai } \\
\text { model }\end{array}$} & \multicolumn{2}{|c|}{ 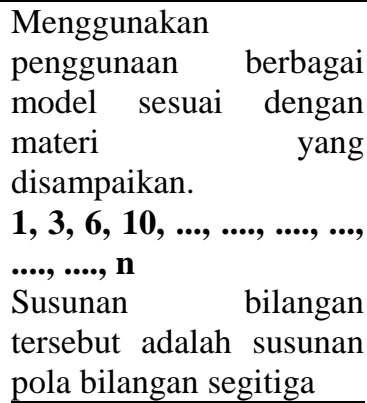 } \\
\hline & & $\begin{array}{l}\text { Pola } \\
\text { ke- }\end{array}$ & Pola bilangan \\
\hline & & 1 & $1=\frac{1}{2} \times 1 \times 2$ \\
\hline & & 2 & $3=\frac{1}{2} \times 2 \times 3$ \\
\hline & & & $=\frac{1}{2} \times \ldots \times \ldots$ \\
\hline & & & $\begin{array}{l}10 \\
=\frac{1}{2} \times \ldots \times(\ldots \\
+\cdots)\end{array}$ \\
\hline & & & $\begin{array}{l}\cdots \\
=\frac{1}{2} \times \ldots \times(\ldots \\
+\cdots)\end{array}$ \\
\hline & & 6 & $\begin{array}{l}\cdots \\
=\frac{1}{2} \times \ldots \times(\ldots \\
+\cdots)\end{array}$ \\
\hline & & $\mathrm{N}$ & $\begin{array}{l}\mathrm{Un}=\frac{1}{2} \times \ldots \times \\
(\ldots+\cdots)\end{array}$ \\
\hline 3 & $\begin{array}{l}\text { Menggunaka } \\
\text { n kontribusi } \\
\text { siswa }\end{array}$ & $\begin{array}{l}\text { Mem } \\
\text { kepac } \\
\text { meny } \\
\text { Sisw: } \\
\text { mem } \\
\text { ada } \\
\text { mend } \\
\text { deng }\end{array}$ & $\begin{array}{l}\text { kesempatan } \\
\text { siswa untuk } \\
\text { apaikan pendapat. } \\
\text { mengamati dan } \\
\text { mi masalah yang } \\
\text { ada LKS dan } \\
\text { usikannya } \\
\text { kelompok. }\end{array}$ \\
\hline 4 & Interaktivitas & $\begin{array}{l}\text { Penje } \\
\text { perse } \\
\text { atau } \\
\text { menc } \\
\text { peng } \\
\text { form } \\
\text { bentu } \\
\text { mate } \\
\text { yang } \\
\text { oleh }\end{array}$ & 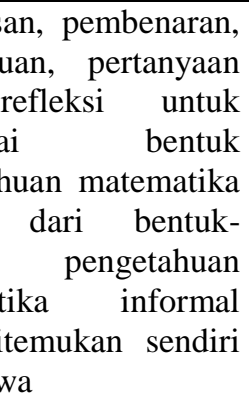 \\
\hline
\end{tabular}




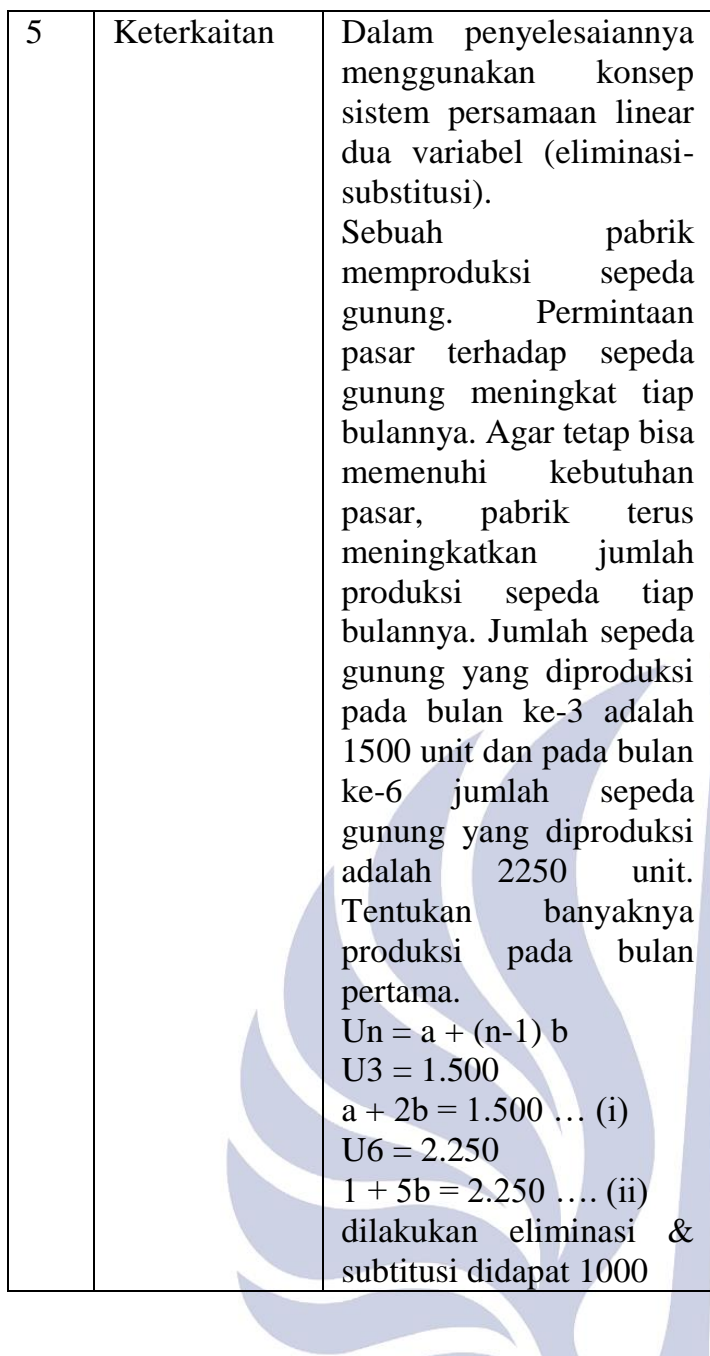

Di awal pembelajaran siswa diberi masalah yang berkaitan dengan lingkungan sekitar. Siswa dibagi beberapa kelompok untuk menyelesaikan soal. Siswa menyelesaikan masalah yang berkaitan dengan pola bilangan segitiga, persegi, dan persegi panjang. Siswa diberi kesempatan untuk menyampaikan pendapat. Di setiap kelompok mendiskusikan masalah yang ada pada LKS dan menyelesaikannya dengan konsep matematika yang lain. Pelaksanaan pembelajaran konvensional di Kelas VIII-F sesuai dengan perangkat pembelajaran. Dalam pembelajaran di kelas guru yang aktif, membahas, dan menjelaskan materi pola bilangan. Guru memberikan contoh dari pola bilangan, kemudian memberi siswa latihan-latihan soal.

Setelah melaksanakan pembelajaran di kelas kontrol dan kelas eksperimen, kedua kelas

Test Statistics $^{\mathbf{a}}$
\begin{tabular}{|lr|l|}
\hline & $\begin{array}{l}\text { Post Test } \\
\text { Kontrol - } \\
\text { Pre Test } \\
\text { Kontrol }\end{array}$ \\
\hline $\begin{array}{l}\text { Z } \\
\begin{array}{l}\text { Asymp. Sig. } \\
\text { (2-tailed) }\end{array}\end{array}$ & $-3.417^{\mathrm{b}}$ \\
.001 \\
\hline
\end{tabular}

melaksanakan posttest. Sebanyak 60 siswa mengikuti posstest. Sebanyak 30 siswa dari kelas kontrol dan 30 siswa dari kelas eksperimen. Pengerjaan posstest membutuhkan waktu 30 menit. Peneliti memberitahu kepada siswa bahwa pengerjaan posstest secara individu dan jujur karena hasil posstest tidak berpengaruh pada nilai sekolah.

Tabel 3. Nilai posttest

\begin{tabular}{|c|c|c|}
\hline \multirow{2}{*}{ No Absen } & \multicolumn{2}{|c|}{ Nilai Posttest } \\
\cline { 2 - 3 } & (VIII-F) & (VIII-G) \\
\hline 1 & 70 & 70 \\
\hline 2 & 60 & 70 \\
\hline 3 & 60 & 70 \\
\hline 4 & 80 & 70 \\
\hline 5 & 70 & 80 \\
\hline 6 & 80 & 80 \\
\hline 7 & 100 & 80 \\
\hline 8 & 80 & 100 \\
\hline 9 & 60 & 70 \\
\hline 10 & 60 & 70 \\
\hline 11 & 60 & 80 \\
\hline 12 & 40 & 90 \\
\hline 13 & 60 & 80 \\
\hline 14 & 60 & 60 \\
\hline 15 & 100 & 70 \\
\hline 16 & 60 & 70 \\
\hline 17 & 80 & 100 \\
\hline 18 & 60 & 80 \\
\hline 19 & 70 & 70 \\
\hline 20 & 60 & 70 \\
\hline 21 & 60 & 70 \\
\hline 22 & 60 & 70 \\
\hline 23 & 70 & 80 \\
\hline 24 & 80 & 70 \\
\hline 25 & 80 & 80 \\
\hline 26 & 40 & 70 \\
\hline 27 & 70 & 80 \\
\hline 28 & 80 & 70 \\
\hline 29 & 60 & 70 \\
\hline 30 & 60 & 70 \\
\hline Jumlah & $\mathbf{2 0 3 0}$ & $\mathbf{2 2 6 0}$ \\
\hline Rata-rata & $\mathbf{6 7 , 6 7}$ & $\mathbf{7 5 , 3 3}$ \\
\hline 869 & 6 & 5051 \\
\hline
\end{tabular}

Berdasarkan Tabel 3, hasil posttest dari Kelas VIII-F diikuti 30 siswa dengan rata-rata 67,67. Sedangkan hasil posttest dari Kelas VIII-G diikuti 30 siswa dengan rata-rata 75,33.

\section{B. Pembahasan}

\section{Analisis Data Kelas Kontrol}

Uji Normalitas

Dalam pengujian Kolmogorov Smirnov, apabila probabilitas lebih dari $0,05 \mathrm{H}_{0}$ dapat diterima namun apabila probabilitas yang didapat kurang dari 0,05 maka $\mathrm{H}_{0}$ ditolak. Diketahui nilai Asymp Sig (2 tailed) dalam Kolmogorov yaitu 0,000. Dimana 0,000 kurang dari 0,05 , berarti distribusi tidak normal.

Karena data yang didapat menunjukan distribusi yang tidak normal, dilakukan uji wilcoxon. Hasil dari uji wilcoxon dengan memakai SPSS-23 pada Tabel berikut 
Uji wilcoxon dilakukan supaya data yang didapat masih bisa di uji. Dasar pengambilan keputusan dalam uji wilcoxon apabila nilai Asymp.Sig. kurang dari $0,05 \mathrm{H}_{0}$ diterima yaitu adanya perbedaan hasil. Dari tabel diatas menunjukan Asymp. Sig. $0.001<0,05$ jadi $\mathrm{H}_{0}$ diterima.

Analisis Regresi

Dalam analisis regresi kita melihat nilai signifikansi dengan probabilitas kemudian dibandingkan.

\begin{tabular}{|l|l|l|}
\hline R Square & $\begin{array}{l}\text { Adjusted R } \\
\text { Square }\end{array}$ & $\begin{array}{l}\text { Std. Error of } \\
\text { the Estimate }\end{array}$ \\
\hline .549 & .542 & 8.75267 \\
\hline
\end{tabular}

Dari tabel di atas diketahui $\mathrm{R}$ yaitu hubungan sebesar 0,416. Hubungan yang dimaksud kelas dan pendekatan yang diberikan. Kemudian dilihat dari $R$ Square yaitu koefisien determinasi sebesar 0,173 artinya pembelajaran yang dilakukan berpengaruh terhadap hasil belajar sebesar 17,3\%. Persentase yang didapat kecil, karena pembelajaran yang dilakukan belum bermakna bagi siswa.

Diketahui dari output nilai constant $(\alpha)$ sebesar 46,333, sedang nilai kelas (b/ koefisien regresi) sebesar 10,667 sehingga persamaaan regresi dapat ditulis sebagai berikut:

$$
\mathrm{Y}=46,333+10,667 \mathrm{X}
$$

Menurut persamaan di atas, konstanta sebesar 46,333 berarti bahwa nilai konsisten pembelajaran melalui pendekatan adalah sebesar 46,333 juga dilihat koefisien regresi X sebesar 10,667. Nilai yang didapat positif, maka disimpulkan bahwa variabel X berpengaruh ke arah positif terhadap variabel Y.

\section{Analisis Data Kelas Eksperimen}

Uji Normalitas

Peneliti menggunakan uji Kolmogorov Smirnov sebagai uji statistik untuk menguji distribusi data normal. Uji normalitas dengan hipotesis:

$\mathrm{H}_{0}$ : Data berdistribusi normal

Ha: Data berdistribusi tidak normal

Dalam pengujian Kolmogorov Smirnov, apabila probabilitas lebih dari $0,05 \mathrm{H}_{0}$ dapat diterima namun apabila probabilitas yang didapat kurang dari 0,05 maka $\mathrm{H}_{0}$ ditolak. Diketahui bahwa Asymp Sig $(2$ tailed) dalam Kolmogorov yaitu 0,000. Dimana 0,000 kurang dari 0,05, ditolak.

Karena data yang didapat menunjukan distribusi yang tidak normal maka dilakukan uji wilcoxon supaya data yang didapat bisa di uji. Dalam uji wilcoxon apabila nilai Asymp.Sig. kurang dari $0,05 \mathrm{H}_{0}$ diterima. Dari tabel diatas menunjukan Asymp.Sig. (2-tailed) $0.000<0,05$ jadi $\mathrm{H}_{0}$ diterima.

\section{Analisis Regresi}

Dalam analisis regresi kita melihat nilai signifikansi dengan probalitas kemudian dibandingkan.

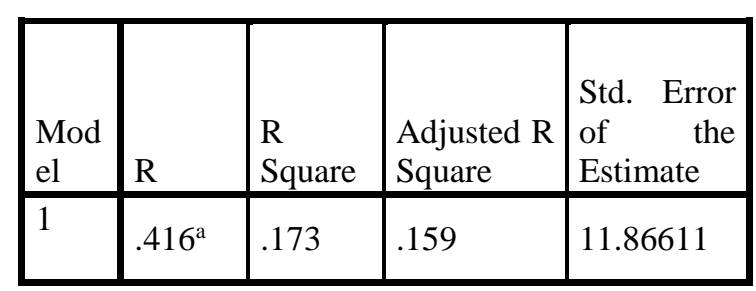

Dari tabel di atas diketahui $\mathrm{R}$ yaitu hubungan sebesar 0,542. Hubungan yang dimaksud kelas dan pendekattan yang dilakukan peneliti. Kemudian dilihat dari $R$ Square yaitu koefisien determinasi sebesar 0,549 artinya pembelajaran yang dilakukan memengaruhi hasil belajar sebesar 54,2\%.

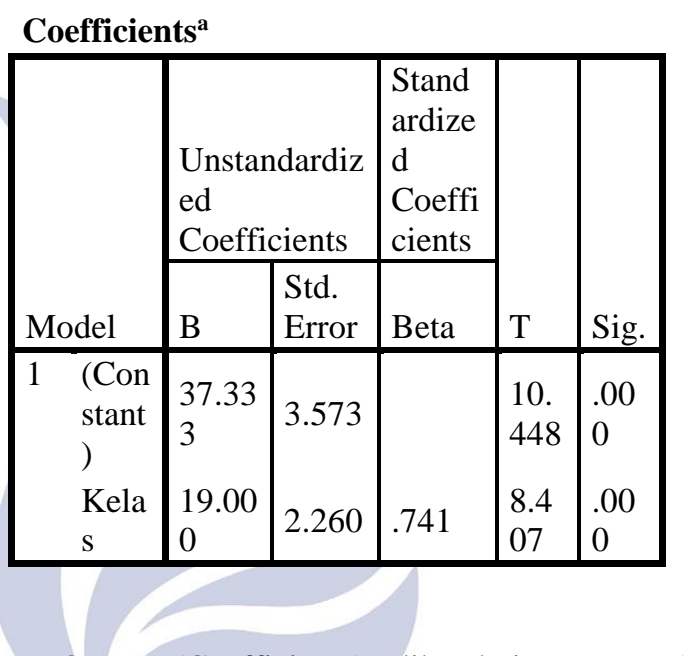

Output (Coefficients), diketahui constant $(\alpha)$ sebesar 37.333, nilai kelas (b/ koefisien regresi) sebesar 19.000 sehingga persamaaan regresi dapat ditulis sebagai berikut:

$$
\begin{aligned}
& \mathrm{Y}=\mathrm{a}+\mathrm{bX} \\
& \mathrm{Y}=37.333+19.000 \mathrm{X}
\end{aligned}
$$

Menurut persamaan di atas, konstanta sebesar 37.000 artinya bahwa nilai konsisten pembelajaran melalui pendekatan adalah sebesar 37.333 juga dilihat koefisien regresi X sebesar 19.000. Koefisien tersebut bernilai positif, sehingga dapat diartikan arah pengaruh pendekatan pembelajaran terhadap hasil belajar pada siswa adalah positif. Dalam uji regresi ini membandingkan nilai signifikansinya sebesar 0,000 kurang dari-0,05 sehingga dapat disimpulkan bahwa variabel $\mathrm{X}$ berpengaruh terhadap variabel Y.

Dari hasil penelitian yang telah dilakukan, pelaksanaan pembelajaran pada kelas kontrol dan kelas

Test Statistics ${ }^{\mathrm{a}}$

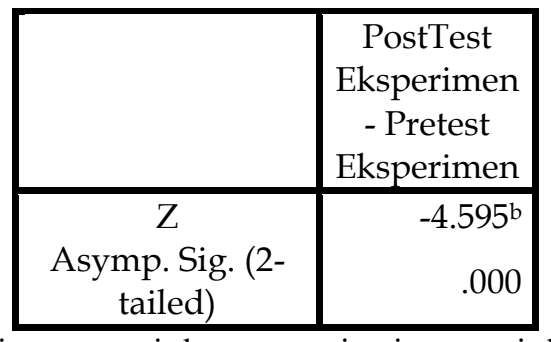

eksperimen sesuai dengan teori yaitu sesuai dengan 
langkah-langkah pembelajaran yang dimaksud. Setelah dilakukan pembelajaran pada setiap kelas, hasil belajar (posttest) yang diperoleh ada perbedaan hasil belajar pada kedua kelas. Hasil belajar pada kelas yang diberi perlakuan yaitu pembelajaran dengan pendekatan PMRI lebih tinggi dari kelas yang diajar dengan pembelajaran konvensional. Data pada kedua kelas telah berdistribusi normal, ada perbedaan hasil antara kelas control dan kelas eksperimen, dan hasil uji $\mathrm{t}$ ada pengaruh pendekatan PMRI terhadap hasil belajar siswa. Dilihat dari hasil perhitungan pada uji-t, nilai signifikansi kurang dari 0,05. Dapat ditarik kesimpulan bahwa pendekatan PMRI dapat memengaruhi hasil belajar siswa.

\section{PENUTUP}

Berdasarkan pada hasil pengujian statistik menggunakan aplikasi SPSS-23 dan pembahasan dari penelitian yang telah dilakukan tentang pengaruh pendekatan PMRI terhadap hasil belajar siswa maka diperoleh kesimpulan bahwa terdapat pengaruh pendekatan PMRI terhadap hasil belajar siswa. Hal ini ditunjukkan oleh nilai perhitungan yang menghasilkan nilai sig. (signifikansi) 0,014 yang berarti kurang dari 0,05 .

Berdasarkan penelitian yang telah dilakukan terdapat beberapa saran yaitu pada penelitian ini data awal berdistribusi tidak normal karena terbatasnya jumlah nilai yang berbeda-beda. Ini dapat diatasi dengan menggunakan sistem pengukuran yang lebih akurat. Hasil penelitian ini menunjukkan adanya pengaruh pendekatan PMRI terhadap hasil belajar siswa. Penelitian ini dapat dilanjutkan dengan menggunakan lain, karena penelitian ini hanya menggunakan masalah materi pola bilangan Kelas VIII.

\section{DAFTAR PUSTAKA}

Arikunto, Suharsimi. 2010. Prosedur penelitian. Jakarta: Renika Cipta.

Ariyadi, Wijaya. 2012. Pendidikan Matematika Realistik, Suatu Alternatif Pendkatan Pembelajaran Matematika. Yogyakarta: Graha Ilmu.

Azizah, Nur. 2015. Penerapan Pendekatan PMRI dalam Pembelajaran Volume Prisma dan Limas di Kelas VIII-B SMP Negeri 26 Surabaya. Jurnal Pendidikan Matematika. Universitas Negeri Surabaya. Vol. 4 (1)

Hadi, Sutarto. 2003. Paradigma Baru Pendidikan Matematika. Banjarmasin: FKIP Universitas Mangkurat.

Izzabella, Erika. 2017. Penerapan Pendekatan PMRI pada Materi Perbandingan di Kelas VIII-F SMP Negeri 1 Turi. Surabaya: UNESA.

Kementerian Pendidikan dan Kebudayaan. 2018. Peraturan Menteri Pendidikan dan Kebudayaan Republik Indonesia Nomor 35 Tahun 2018 Tentang Kurikulum 2013 Sekolah Menengah Pertamal Madrasah Tsanawiyah. Jakarta: Kemdikbud.

Puspendik. 2018. Laporan Hasil UN 2018 Update. Jakarta: Puspendik.

Putri,R.I.I., \& Zulkardi. 2019. Designing jumping task on percent using PMRI and collaborative learning. International Journal on Emerging Mathematics Education, 3(1), 105-116.

Rosyada, D. 2004. Paradigma Pendidikan Demokratis. Jakarta: Kencana.

Soedjadi. 2000. Kiat Pendidikan Matematika di Indonesia. Jakarta: Ditjen Dikti Depdikbud.

Suharta Putu, I.G. Vol 38 no 4 Tahun 2005. Pengembangan Perangkat Pembelajaran Pecahan Dengan Menggunakan Pendekatan Matematika Realistik (PMR).

Suwarsono. 2001. Pendidikan Matematika di Indonesia. Jakarta: Depdiknas.

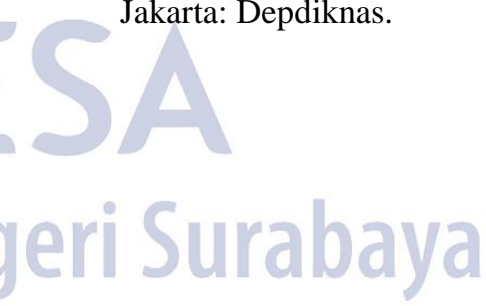

